\title{
Dolan Desoboro Educational Tourism as a Choice of the Lexicon Preservation Strategies of 'Rice Field' in Banjarasri Village, Kulonprogo, Yogyakarta
}

\author{
$1^{\text {st }}$ Lien Darlina \\ Tourism Department \\ Politeknik Negeri Bali \\ Badung, Bali, Indonesia \\ darlina@pnb.ac.id
}

\author{
$2^{\text {nd }}$ Harisal \\ Tourism Department \\ Politeknik Negeri Bali \\ Badung, Bali, Indonesia
}

\section{INTRODUCTION}

Abstract - This study examines Dolan Desoboro Educational Tourism as a choice of lexicon preservation strategies of 'Kepadian Sawah' in Banjarasri Village, Kulonprogo, Yogyakarta. However, there are two problems of this study, such as (1) How is the linguistic form of the lexicon 'Kepadian Sawah' Javanese speech community in Banjarasri village, Kulonprogo, Yogyakarta?, and (2) What is the strategy used by Dolan Desoboro Edu-Turism in order to preserve the ecolexicon 'Kepadian Sawah' in the Banjarasri village, Kulonprogo, Yogyakarta?. Moreover, the eco-linguistic theory is implemented in regard to analyzing the forms and meanings of the eco-lexicon 'Kepadian Sawah' on intrathtuality, intertextuality, extrattuality, interconnection and interdependence aspects, as well as EduTourism theory. The results showed that the linguistic form of agricultural ecolexicon of 'Kepadian Sawah' in Javanese speech community that used in Edu-Tourism Dolan Desoboro are rice pre-plant (land preparation), there are $\mathbf{1 7}$ forms of ecolexicon, consisting of 7 verbs $(\mathrm{V})$, and 10 nouns $(\mathrm{N})$, while in rice planting and harvesting process, there are 22 forms of ecolexicon, consisting of 12 verbs $(\mathrm{V})$, and 10 nouns $(\mathrm{N})$, furthermore, such as kebo 'buffalo', pacul 'hoe', macul 'hoeing', ngluku 'to plough a field', nggaru 'shatter and flatten the soil surface after the nggaru process', tamping 'cleaning the rice field and others, (2) Rice planting method, there are 21 forms of ecolexicon of rice planting and harvesting process, consisting of 11 verbs $(V)$, and 10 nouns (N), including: pari 'rice', wineh pari 'seed', nandur 'handbroadcast seeding', naleni wenih pari 'binds the seedlings', yellow pari dadine 'the rice ready for harvest when the grain turned to yellows', pari ijo dadine 'the apperance of rice stem', wayahne panen 'harvest season', ani-ani a tool for picking grains', methik pari 'picking grain', and Wiwitan upacara' the preparation cerommony of rice cutting'. However, The strategy used in Dolan Desoboro Edu-Tourism to preserve the agricultural lexicons is the use of local language in 'Live In package' tourism activities, including staying in a house, processing land, planting and harvesting rice, and bathing buffalo.

Keywords: Eco-lexicon, Eco-linguistic, Edu-Tourisn, Tourism
The existence of human being is an ecosystem with other human being, both with the natural environment and sociocultural environment. However, the relationship between language and environment are created the concepts of the environment of language and the language environment (Mbete, 2011). Moreover, as a cultural means and lingual code language are representative of the real world that can be sensed as facts about human knowledge and comprehension related to the world (world view), both natural or artificial environment (built environment) which are dimensioned to human life. It also has a fuction as an invisible reality recorder, such as science, religion, and cultural society.

There is a number of etnics group in Indonesia that have a unique to express their own language. However, the uniqueness of the way expressing their regional language is reflected the diversity of reality and culture behind it. Moreover, along with the globalization, the threatening of extinction of local languages has become an international problem, and it is predicted that $50 \%$ of the 6.700 languages in the world will be extinct by the end of the century (Mbete, 2010). Therefore, it is important to take intensive attention to the local languages must involved the government, academics and the community as an effort to preserve its sustainability.

There is a sustainable tourist destinations named Dolan Desoboro that located around the Menoreh hill, with neatly arranged rice field, river and verdant trees This destination is a new phenomenon for Edu-Tourism that managed by the villager in Banjarasri village in regard to preserve the nature, culture and ecolexicon of 'Kepadian Sawah'. However, this sustainable tourism destination offers a recreation and education threats, so that the tourists get knowledge and insight along with new experiences in both physically or psychologically from this place.

Based on the background of study above, there are two limits problems of research study, such as: (1) How is the linguistic form of the lexicon 'Kepadian Sawah' Javanese speech community in Banjarasri village, Kulonprogo, Yogyakarta?, and (2) What is the strategy used by Dolan 
Desoboro Edu-Turism in order to preserve the ecolexicon 'Kepadian Sawah' in the Banjarasri village, Kulonprogo, Yogyakarta?. In addition, the aims of study are such as follows: (1) To identify the linguistic form of the lexicon 'Kepadian Sawah' Javanese speech community in Banjarasri village, Kulonprogo Yogyakarta, and (2) To identify what is the strategy used by Dolan Desoboro Edu-Turism in order to preserve the ecolexicon 'Kepadian Sawah' in the Banjarasri village, Kulonprogo, Yogyakata.

\section{RESEARCH METHOD}

The research method used in this study is qualitative method in accordanc to get facts and information about the richness of the lexicon ideological-biologies and the strategy to preserve the lexicon 'Kepadian Sawah' of Dolan Desoboro for the managements or tourists. Meanwhile, there are two data sources. Moreover, the written data that get from interviewed from the informants and the result of the instrument from the respondents used as sampled as well as the data from documents related to this research. Besides that, the primary data of this study is the data taken from the managements and tourists.

The processing data used a distributional method, namely, by grouping the lexicon forms according to its function process of the lexicon 'Kepadian Sawah' that will be done in every Edu-Tourism Dolan Desoboro activities. According to Moleong (2002:103) the analysis data as the proses of organizing and numbering data into patterns, categories, and basic unit descriptions so that themes can be found. In adition, the data that obtained by interviwed, lexicon competency test, observation, and documentation (by recorded and written techniques) would be separated into group of lexicon and described into units, and make a simple conclusion that easy to be understand. Furthermore, the data analysis would be analyze based on the ecolinguistic theory and Edu-Tourism by using qualitative methods.

\section{RESULTS AND DISCUSSION}

The analysis of the linguistic form of the lexicon 'Kepadian Sawah' denoted as an Edu-Tourism activity package, which carried out and presented into ecolexicon and discourse 'Kepadian Sawah' based on intrathtuality, intertextuality, and extrattuality aspects.

\section{A. Ecolexicon 'Kepadian Sawah'}

The lexeme ecolexicon is commonly called vocabulary. It is a language component that contains of information about form, meaning and word usage in languages (Kridalaksana, 2008). According to Sapir vocabulary is reflected a physical environment and human society. In the other hand, it is reflected the character limits of the physical environment and the cultural character of the people who use it (in Fill and Muhlhatisler, 2001: 14). However, it is a set of terms in an event environment that reflects the character of the speech community, the nature of the natural environment, and the socio-cultural environment. Based on the Edu-Tourism activities of Dolan Desoboro the ecolexicon that found aims to preserve the local language by promoting 'Live In Package 'activities, such as of how to cultivate rice, process rice to harvest, and its supporting factors. It is included the lexicon 'Kepadian Sawah' of pre-plant process (land preparation) and post-planting stages.

\section{1) Pre-plant Stages}

Pre-plant stage is a land preparation before the seed (pari) ready to be crop in the field. In addition, every activities, processes, circumtances, or objects related to the lexicon 'Kepadian Sawah' in the pre-plant stage is realized into certain lexicons. Moreover, the processes and activities at the pre-plant stage related to land preparation. In the other hand, the vocabulary of the lexicon 'Kepadian Sawah' of the Javanese speech community in Banyuasri village, Kulonprogo, Yogyakarta is grouped according to its form, meaning and categories including verb, noun, and adjective.

TABle 1 Pre-Plant Stages of Rice (LAND PREPARAtion)

\begin{tabular}{|c|c|c|c|c|c|}
\hline \multirow{2}{*}{ No. } & \multirow{2}{*}{ Lexicon } & \multirow{2}{*}{ Meaning } & \multicolumn{3}{|c|}{ Categories } \\
\hline & & & V & $\mathrm{N}$ & Adj \\
\hline 1 & Kali & River & & $\mathrm{V}$ & \\
\hline 2 & Got & Sewers & & $\mathrm{v}$ & \\
\hline 3 & Kebo & Buffalo & & $\mathrm{v}$ & \\
\hline 4 & Sapi & Cow & & $\mathrm{v}$ & \\
\hline 5 & Pacul & Hoe & & $\mathrm{v}$ & \\
\hline 6 & Luku & $\begin{array}{l}\text { A traditional tool for shattering the soil } \\
\text { surface }\end{array}$ & & $\mathrm{v}$ & \\
\hline 7 & Ngluku & To plaugh a field & $\mathrm{V}$ & & \\
\hline 8 & Kejen & Luku's tool head & & $\mathrm{v}$ & \\
\hline 9 & Garu & $\begin{array}{l}\text { Traditional plowing tools to destroy } \\
\text { soil }\end{array}$ & & $\mathrm{v}$ & \\
\hline 10 & Nggaru & $\begin{array}{l}\text { Shatter and flatten the soil surface } \\
\text { after Nggaru process }\end{array}$ & $\mathrm{v}$ & & \\
\hline 11 & Tamping & Cleaning the rice field & $\mathrm{V}$ & & \\
\hline 12 & Suket & Grass & & $\mathrm{v}$ & \\
\hline 13 & Mopok & $\begin{array}{l}\text { Fertilization the soil after tamping } \\
\text { process }\end{array}$ & $\mathrm{V}$ & & \\
\hline 14 & Ndaut & $\begin{array}{l}\text { Revoking the seeds that ready for } \\
\text { planting }\end{array}$ & $\mathrm{V}$ & & \\
\hline 15 & Lep & $\begin{array}{l}\text { Irrigating water to the plot of the rice } \\
\text { fields from the ditch. }\end{array}$ & $\mathrm{V}$ & & \\
\hline 16 & Galengan & A rice field dike & & $\mathrm{v}$ & \\
\hline 17 & Ngadusi kebo & Bathing buffalo & $\mathrm{V}$ & & \\
\hline
\end{tabular}

The vocaulary of the lexicon of Javanese speech community in Banyuasri, Kulonprogo, Yogyakarta, which was used in Dolan Desoboro Edu-Tourism activities as an effort to preserve the local language, there are 17 pre-plant or land preparation of ecolexicon forms, consisting of 7 verbs (V), and 10 nouns $(\mathrm{N})$.

As examples such as follows: (1) the lexeme ngluku is a land preparation process before planting, the soil needs to be prepared, so its nutrient is stable. It needs to be 'reserved, the soil layer below is moved upwards and vice versa. It aims to 
homogenize the land so that it is ready to be planted. Moreover, this activity is alsoaims to keep the fertilization of the soil. However, regarding to this activity, it needs a special tool called luku 'plow' and it is synonymous to plough and tenggala. In addition, it is pulled by a buffalo so that the stage of reversing the soil takes a long time. The activity of plowing fields before the rice planting period is called ngluku (2) the lexeme nggaru is the activity after ngluku which in common called nggaru. The basic form of the word ngaru is come from the word garu 'soil scracth tool'. Furthermore, this process is aim to shatter the surface of the soil before its ready to be seedlings, (3) the lexeme pacul, pacul or hoe 'a tool for excavate and scramble the soil, it is made from iron and it has long stalk handle. Addionally, these three lexemes (luku, nggaru, and pacul) mentioned above were registered into KBBI dictionary.

\section{2) Rice Planting Method and Harvesting Process}

The rice planting method is a process after land prepararion with all sorts of other activities so it ready to be planting.

Table 2 Rice Planting Method and Harvesting Process

\begin{tabular}{|c|c|c|c|c|c|}
\hline \multirow{2}{*}{ No. } & \multirow{2}{*}{ Lexicon } & \multirow{2}{*}{ Meaning } & \multicolumn{3}{|c|}{ Categories } \\
\hline & & & $\mathbf{V}$ & $\mathbf{N}$ & Adj \\
\hline 1 & Pari & Rice & & $\mathrm{V}$ & \\
\hline 2 & Wineh pari & Seed & & $\mathrm{V}$ & \\
\hline 3 & Ndaut & $\begin{array}{l}\text { Revoking the seeds that } \\
\text { ready for planting }\end{array}$ & $\mathrm{v}$ & & \\
\hline 4 & $\begin{array}{l}\text { Naleni wenih } \\
\text { pari }\end{array}$ & Binds the seddlings & $\mathrm{v}$ & & \\
\hline 5 & Tandur & Hand-broadcast seeding & $\mathrm{v}$ & & \\
\hline 6 & $\begin{array}{l}\text { Parine dadi } \\
\text { kuning }\end{array}$ & $\begin{array}{l}\text { The rice is ready for harvest } \\
\text { when the grain turned to } \\
\text { yellows. }\end{array}$ & & v & \\
\hline 7 & Parine dadi ijo & The apperance of rice stem & & $\mathrm{V}$ & \\
\hline 8 & $\begin{array}{l}\text { Wayahe } \\
\text { panen }\end{array}$ & Harvest season & & v & \\
\hline 9 & Mlecuti & The rice plant blossom & & $\mathrm{v}$ & \\
\hline 10 & Mrekatak & The appearance of the grains & & $\mathrm{V}$ & \\
\hline 11 & Tumungkul & $\begin{array}{l}\text { The rice plant bow to the } \\
\text { earth }\end{array}$ & & $\mathrm{V}$ & \\
\hline 12 & Ndangak & The empty peel & & $\mathrm{V}$ & \\
\hline 13 & Gembrang & $\begin{array}{l}\text { The grain is empty caused of } \\
\text { paddybird }\end{array}$ & & $\mathrm{V}$ & \\
\hline 14 & Wiwit & $\begin{array}{l}\text { The preparation ceremmony } \\
\text { of rice cutting }\end{array}$ & $\mathrm{V}$ & & \\
\hline 15 & Ani-ani & $\begin{array}{l}\text { Ani-ani (a tool for picking } \\
\text { grains) }\end{array}$ & & $\mathrm{v}$ & \\
\hline 16 & Methik pari & Picking grains & $\mathrm{V}$ & & \\
\hline 17 & Panen & Harvest & $\mathrm{v}$ & & \\
\hline 18 & Matun & $\begin{array}{l}\text { Revoke the weed and wild } \\
\text { grass which fetched the rice } \\
\text { nutrients }\end{array}$ & $\mathrm{v}$ & & \\
\hline 19 & $\begin{array}{l}\text { Nggaruk/Osro } \\
\mathrm{k}\end{array}$ & $\begin{array}{l}\text { Clear the rice plant used } \\
\text { scratch tool }\end{array}$ & $\mathrm{V}$ & & \\
\hline 20 & Nggepyok & $\begin{array}{l}\text { Sheding the grains from its } \\
\text { plant }\end{array}$ & $\mathrm{V}$ & & \\
\hline 21 & Derep & $\begin{array}{l}\text { Harvesting the rice plant used } \\
\text { ani-ani }\end{array}$ & $\mathrm{v}$ & & \\
\hline
\end{tabular}

The vocabulary of the lexicon Javanese speech community in Banyuasri village, Kulonprogo, Yogyakarta, which was used in Dolan Desoboro's Edu-Tourism activities as an effort to preserve rice cultivation and the process until its harvest, there are 21 forms of ecolexicon, consisting of 11 verbs $(\mathrm{V})$, and 10 nouns $(\mathrm{N})$.

Javanese speech community in the Banyuasri is one of the examples of a linguistic relationship. They are agreed to use the Javanese language aspects in their daily communication. Moreover, how they determine every word or term, how they used that term in right context is definitely as in common agreement by the community who work as rice farmers, and they having their own lexicon that they used in agriculture terms. Thus, however, it will be exemplified by several lexemes that related to the example above, for einstances, the lexeme tandur (hand-broadcast seeding), wineh pari and others which are abstract forms that underlie inflective forms of planting, cultivating, and planting. A collection of lexemes in a language is called lexicon. In other word, lexicon is a collection or vocabulary of words that exist in a language. Beside that, this lexicon also refers to linguistic word that knowledge by the people. For example, the lexicon above are exemplified by several lexemes as follows: (1) the lexeme of tandur or nandur is the hand-broadcast seeding activity on wider fields. It is come from the basic form of tandur 'planting'. In addition, the tandur laborers who are usually a group of women form a line and simultaneously plant rice seeds guided by a device made of bamboo stalks about five meters long which is called blak, so that the plants are straight and the spacing is the same and regular. Then, (2) the lexeme of winih or seeds are rice seeds that are ready to be sown. The soil of the fields that previouly processed is usually relatively flat and soft. After that, the farmers determine a certain part of the rice field as a nursery, not necessarily too broad, usually about ten to fifteen square meters in size depending on the number of seeds.

\section{B. The Strategy of Dolan Deso Boro Tourism in the Preservation of Agricultural Ecolexicon of 'Kepadian Sawah' in Banyuasri Village}

Defending or shifting a language, both in minority groups and in transmigrant immigrant groups can be caused by many factors, Fishman (1972) states that one of important factors to maintaining a language is the existence of the loyalities of the supporting community.

\section{1) Overview and Dolandesoboro Edu-Tourism Activity in Banyuasri Village, Kulonprogo, Yogyakarta}

Dolan Deso Boro (DolanNdeso) is a tourist spot that located in Boro distict, Banjarasri village, Kalibalang subdistrict, Kulonprogo regency, that has a traditional concept that promotes an environmental conservation and based on its culture value and local wisdom. In accordance to its slogan 'Culture for Nature', the traditional concept of dolandeso can be seen from buildings that are in an area of 4 hectares that is coupled with rice field, lake and river that make us feel at home for long here. Moreover, Dolan Desoboro Edu-Tourism concept is a sustainable tourism, either in culture, language, and the preservation of the natural environment. This tour 
started from capital minus 2 but with enthusiasm plus 9, $\mathrm{Mr}$. Hartono as the initiator said so. It was established in 2011, located in a minus and dry area. It is located above 4 ha of village customary land, with annual rent of 6 million rupiahs and now has developed rapidly to handle 6 Edu-Tourism Villages.

The segmentation of Dolan Desoboro Tourism is based on markets that focus on tourism activities (tourism first) which is a tourism program for adult students (senior) where a number of forms of learning activities become an important part of tourism activities and focus on education (education first) which is a programme where activities tourism as the main destination. Besides that, it combines with the potential of the village into a place of community education with its educational tours.

Dolan Desoboro tourism facilities consist of meeting rooms, homestays, toilets, playgrounds, fields, ponds, rice fields, rivers, small mosque, wheelchair access and residents' houses as the place for the Live In package. In addition, it is supported by the availability of Limasan houses to stay, with a capacity of 40 to 120 people plus a total of 18 MCK facilities. A variety of attractive tour packages with natural nuances of rural and culture are packed in Culture for Nature, and equipped with venues of typical Javanese houses like Joglo and Pavilion (Pendopo) that we can enjoy with our colleagues or relatives with a cool atmosphere that accompany we do some activities.

Dolan Desoboro Edu-Tourism Activity in Banyuasri village, Kulonprogo Yogyakarta is managed in accordance with the existing Village potential. Furthermore, the tour packages are such as follows: (1) the 'Live In package', a stay package at a resident's house, usually called 'Live In package' to stay at home around DolaNdeso villagers for several days and follow all the activities of homeowners such as raising livestock, farming or gardening, or selling on the market, such as one TV program 'Jika Aku Menjadi'; (2) Camping package is a package to stay in a tent; (3) Outbound package; (4) Village Cycling; (5) Rafting Package

2) The Strategy to Presrve the Lexicon 'Kepadian Sawah' of Dolan Desoboro Edu-Tourism, Banyuasri Village, Kulonprogo, Yogyakarta

The agricultural lexicon preservation strategy especially the the lexicon 'Kepadian Sawah' in Dolan Desoboro is through the Live In package activity. The Live In package activity is a stay package at a resident's house, usually called Live In package to stay at home around DolaNdeso villagers for several days and follow all the activities of homeowners such as raising livestock, farming or gardening, or selling on the market, such as one TV program 'Jika Aku Menjadi'. Beside that, visitors also learned of how to farm, especially in cultivating rice, planting rice, harvesting and maintaining buffalo or cattle. In addition, they can also enjoy the art of 'Gejog Lesung' which is exists in the surrounding of the community.

\section{CONCLUSION}

The results showed that the linguistic form of agricultural ecolexicon of 'Kepadian Sawah' in Javanese speech community that used in Edu-Tourism Dolan Desoboro are rice pre-plant (land preparation), there are 17 forms of ecolexicon, consisting of 7 verbs $(\mathrm{V})$, and 10 nouns $(\mathrm{N})$, while in rice planting and harvesting process, there are 21 forms of ecolexicon, consisting of 11 verbs (V), and 10 nouns $(\mathrm{N})$. Moreover, theses lexicons include: pari (rice), wineh pari (rice seeds), nandur (hand-broadcast seeds), luku (plow tool), pacul (hoe), kebo (buffalo), galeng (rice field dike), kali (rivers), got (sewers), and others. Every lexicon has a spesific meaning, such as the lexicon $n g l u k u$. It is the activity of plowing fields before the rice planting period so that its nutrients stable. Moreover, it aims to hegemonize the soil to be ready for crop and it needs a special the soil upwards called luku 'plough'.

The strategy used in Dolan Desoboro Edu-Tourism to preserve the agricultural lexicons is the use of local language in 'Live In package' tourism activities, including staying in a house, processing land, planting and harvesting rice, and bathing buffalo.

\section{REFERENCES}

[1] Basrowi dan Suwandi. 2008. Memahami Penelitian Kualitatif Jakarta: Rineka Cipta.

[2] Chaer, Abdul. 2006. Linguistik Umum. Jakarta: Rineka Cipta.

[3] Endraswara, Suwardi. 2003. Metodologi Penelitian Kebudayaan. Yogyakarta: Gadjah Mada University press.

[4] Emzir. 2010. Metodologi Penelitian Kualitatif Analisis Data. Jakarta: Rajawali Press.

[5] Fishman, J.A. 1968. The Sociology of Language. Massachusett: Newbury House Plublication Gagasan Fishman

[6] Ginanjar, A., 2012. Kaji Potensi Pariwisata Berbasis Masyarakat Melalui Pengembangan Desa Wisata Peternakan Di Pangelangan Kab. Jawa Barat. Skripsi . UPI.

[7] Gunarwan, Asim. 2006. Kasus-Kasus Pergeseran Bahasa Daerah Akibat Persaingan dengan Bahasa Indonesia. Jurnal Ilmiah Masyarakat Linguistik Indonesia. Edisi 24. Nomor 1, Februari 2006.

[8] Halliday. 1997. Explorations in The Function of Language. London : Edward Arnold.

[9] Hariyanto. 2017. Leisure Time, Leisure Activities And Society Happiness Index In Bandung. International Journal of Scientific \& Technology Research vol 6, Issue 10, October 2017 ISSN 227-8616.

[10] Mbete, Aron Meko. 2001. Ungkapan-Ungkapan dalam Bahasa dan Fungsinya dalam Melestarikan Lingkungan. Linguistika. Vol.9: No. 17. Program Studi Magister dan Doktor Linguistik Universitas Udayana, September 2002.K. Elissa, "Title of paper if known," unpublished.

[11] Mbete, Aron Meko. 2007. Ekolinguitik: Perspektif Kelinguistikan yang Prospektif. Makalah dalam Mahasiswa Jurusan Bahasa dan Seni, UNS, Semarang. 